\title{
QIBLA JURISPRUDENCE:
}

Deviation of Mosques' Qibla in Pamekasan Madura

\author{
Abdul Jalil ${ }^{*}$, Hosen ${ }^{* *}$ \\ *Hukum Keluarga Islam, Institut Agama Islam Negeri Madura, Pamekasan, Indonesia \\ **Hukum Keluarga Islam, Institut Agama Islam Negeri Madura, Pamekasan, Indonesia
}

email: *jllhasan683@gmail.com, **hosen@iainmadura.ac.id

\section{ABSTRACT}

The qibla direction of some mosques in Pamekasan encountered deviation after the recalibration was carried out, but only a few mosques changed their qibla direction according to the calculation of hisâb. This study discusses three issues, namely: Society's understanding of the direction of the mosque's qibla, their responses to deviations from the direction of the mosque's qibla, and the implications of the deviation of the mosque's qibla on the validity of prayer in the perspective of falak science and Islamic law. With a qualitative-descriptive approach based on semi-structured interviews and nonparticipant observation, this study reveals that some congregants still regard the west as the direction of the qibla and do not understand the provisions of having to face the qibla during prayers; there are three axes of the congregation's response to the deviation of the direction of the mosque's qibla, namely serious, ordinary, and indifferent; and mosques that experience deviation according to astronomy are not following the provisions facing the qibla, so they must be repaired so that the prayers are perfect according to the provisions of Islamic law.

\section{ABSTRAK}

Sebagian arah kiblat masjid di Pamekasan mengalami deviasi setelah rekalibrasi dilakukan, tetapi hanya sedikit masjid yang mengubah arah kiblatnya sesuai perhitungan ilmu hisab. Artikel ini mendiskusikan tiga persoalan, yaitu: pemahaman masyarakat tentang arah kiblat masjid, respons masyarakat terhadap penyimpangan arah kiblat masjidnya, dan implikasi deviasi arah kiblat masjid terhadap keabsahan salat dalam perspektif ilmu falak dan hukum Islam. Dengan pendekatan kualitatif-deskriptif berdasarkan wawancara semi terstruktur dan observasi nonpartisipan, artikel ini mengungkap bahwa sebagian jemaah masih menganggap arah barat sebagai arah kiblat dan tidak memahami ketentuan harus hadap kiblat saat salat; ada tiga poros respons jemaah terhadap deviasi arah kiblat masjidnya, yaitu serius, biasa, dan cuek; dan masjid yang mengalami deviasi menurut ilmu falak tidak sesuai dengan ketentuan menghadap kiblat, sehingga harus diperbaiki agar salat menjadi sempurna sesuai ketentuan hukum Islam.
ARTICLE HISTORY

Received 26 May 2019

Accepted 3 October 2020

\section{KEYWORDS}

Astronomy; deviation; Islamic jurisprudence; prayer; qibla 


\section{Introduction}

The mosque as a means of worship for muslims should be able to provide peace for its users.

The comfort expected by its users is not only its physical building but also the spiritual and sharia aspects of a mosque must be fulfilled for the sake of sincerity in performing worship, that is, the mosque must lead towards qibla. In Arabic, qibla comes from the word "qiblah". Qibla is a building similar to a cube, which was in the Arabs' tradition called the Kaaba. The Kaaba was initially ruled by the Quraish. They were proud and enslaved themselves by managing the Kaaba. ${ }^{1}$

Prophet Muhammad PBUH brought Islam religion which contained the command of prayer for the believers. The qibla being initially used was not the Kaaba but Baitul Maqdis in Jerusalem, ${ }^{2}$ Palestine. Allah the Almighty had just ordered the displacement of the direction of qibla from Baitul Maqdis to the Kaaba about 16 or 17 months after the Prophet migrated to Medina, as He said in surah al-Baqarah (2): 144. The event was the beginning of the obligation for muslims during prayers, both obligatory prayers and sunnah prayers, so that the prayers of people who did not face towards the Kaaba were not valid, whether they were near from the Kaaba that they could see it directly or they were so far away from it that they could not see it, including the people of Indonesia.

The displacement of the qibla direction from Baitul Maqdis to the Kaaba sparked controversy, both among muslims, the Quraish, and the Jews. They considered the Prophet to return to the teachings of his ancestors because at that time the Kaaba was still surrounded by many idols. In fact, some of them accused the Prophet of inconsistency. The Jews considered the teachings of the Prophet only imitated the teachings of their religion because the Prophet took Baitul Maqdis as qibla. In fact, the position of Jerusalem and the Kaaba is the same before Allah the Almighty. The displacement ofqibla was only to test humans' obedience to Allah and His messenger. From that event, the people of the Prophet Muhammad PBUH were obliged to face towards the Kaaba. However, some scholars differed on the procedure for dealing with it. ${ }^{3}$

Based on surah al-Baqarah (2): 144, the Kaaba is the direction of the qibla of the muslims during prayers, both those around Mecca and those outside. Geographically, Indonesia is located southeast of Mecca, Saudi Arabia, so the qibla direction of the Indonesian population

\footnotetext{
${ }^{1}$ Susiknan Azhari, Ilmu Falak: Teori dan Praktek (Yogyakarta: Lazuardi, 2001), p. 53.

${ }^{2}$ Departemen Agama RI, Pedoman Penentuan Arah Kiblat (Jakarta: Dirjen Bimbaga, 1994), p. 60.

${ }^{3}$ Ibid., p. 62. 
based on the calculation of arithmetic is to the west which is slightly sloping to the north between 21 to 27 degrees according to the coordinate point of each region. Therefore, the places of worship, mosques or langgar (prayer-house), where the direction of the buildings are less than 21 and more than 27 degrees being calculated from west to north, the direction of prayer in those worship places is not facing the qibla. The determination of qibla direction of the mosque should be done correctly and accurately based on the Islamic science of calculation (hisâb), not merely pointing the direction without having the knowledge of the rules of determining the direction of qibla, such as only facing to the west, with the help of a compass or not, and pointing the west slightly slantwise to the north without paying attention to the magnitude of the angle, because such direction of qibla is not precise towards the Kaaba in Mecca.

There are several studies on the problem of qibla direction: first, it was conducted by the community service lecturer team of STAIN Pamekasan in 2005. The study was focused on five mosques in Pamekasan, Tlanakan, Galis, Larangan, and Kadur Districts. ${ }^{4}$ That study differs from this study in its location and method. The second was a study on the accuracy of the qibla direction of mosques in Pamekasan regency which selected 55 mosques in Pamekasan without mentioning the sample in each district. The analysis focuses on the magnitude of deviation in general and uses the spherical trigonometric method (spherical triangle) with the aid of a magnetic compass so that the object, analysis, and results are different from this study. The third was a study on the accuracy of the mosque's qibla direction using the Mizawala Qibla Finder (MQF) method at 21 mosques in Pademawu District, Pamekasan.

This study shows that only six mosques out of 21 mosques which have an accurate qibla direction facing toward the Kaaba, while the rests have a deviation ${ }^{5}$ because almost $95 \%$ use a compass and prayer mat compass as measurement tools without any prior calculations. ${ }^{6}$ The use of the compass as a measuring tool is merely based on estimations. The mosques that experience a deviation from the qibla direction raise the problem of changing the prayer lines (shaf al-shalâh) and dividing the congregation into two groups, namely the group that is still in

\footnotetext{
${ }^{4}$ Achmad Mulyadi et. al., Penentuan Waktu Shalat 8 Kalibrasi Arah Kiblat: Menakar Problematika Akurasi Masjid-masjid di Pamekasan Melalui Pengabdian Kepada Masyarakat Berbasis Syariah/Hukum (Sumenep: Al-Fatah, 2016)

${ }^{5}$ Ghafiruddin, Akurasi Arah Kiblat Masjid di Wilayah Kecamatan Pademawu Kabupaten Pamekasan Menurut Metode Pengukuran Mizwala Qibla Finder (MQF) (Thesis, STAIN Pamekasan, 2018), p. 58-78. 
the original qibla direction and the group following the corrected prayer lines so that the prayer lines is not neatly and irregularly organized.

This study follows up the previous studies on the third point in Pademawu district, Pamekasan, with a focus on congregations in nine mosques that experienced a deviation of the qibla direction of more than three degrees, both to the north and to the south. This study discusses three problems, namely: society's understanding of the direction of the mosque's qibla, society's response to the deviation of the mosque's qibla, and the implications of the deviation of the mosque's qibla on the validity of prayer from the perspective of astronomy and Islamic law. This study also reveals the problematic changes of prayer lines which have become a hot issue among mosque congregations, and even triggered controversy in certain mosques, so that the congregation's prayer lines is split into two directions; following the changes to the new saf or keeping following the old saf according to the direction of the mosque building and its beliefs. This point is based on an initial investigation on mosques whose qibla deviation exceeds 10 degrees.

This study is as the result of qualitative-descriptive field research because the object requires comprehensive research from all its aspects so that it can describe the real conditions. Data collection was obtained through interviews, non-participant observation, and documentation. The analysis is carried out through data reduction, summarizing, selecting the main things in the form of appropriate data, focusing, presenting a brief description and a relationship with the theory that has been presented, verifying, and concluding the findings.

\section{Qibla Direction: A Concept}

Qibla is a direction that Muslims must point to when performing some rituals of worship, namely the cube building known as the Kaaba. A Muslim who prays in the Great Mosque of Mecca (al-Masjid al- Harâm) is obliged to present himself straight to the position of the Kaaba ('ain al-Ka'bah); a Muslim who prays in the Holy Land of Mecca simply faces towards al-Masjid al- Harâm in which there is the Kaaba; and a muslim in various parts of the world far from the position of the Kaaba is sufficient to face the Holy Land or Mecca. This provision is based on the hadith of the Prophet Muhammad PBUH narrated by al-Baihaqî (994-1066) in al-Sunan alKubrâ from Abû Hurairah (598-678) as follows:

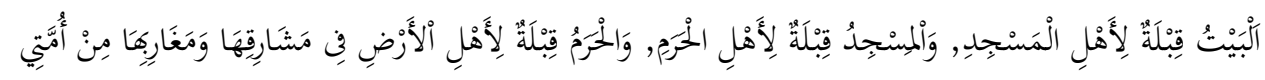


"Baitullah (Kaaba) is the qibla for the people in the Holy Mosque, the Holy Mosque is the qibla for the inhabitants of the Holy Land (Mecca), and the Holy Land (Mecca) is the qibla for the inhabitants of the earth as a whole."

Etymologically, qibla means the Kaaba ${ }^{8}$ or the direction to the Kaaba in Mecca at the time of prayer. ${ }^{9}$ In terms of terminology, the meaning of qibla varies widely, namely: the direction aimed by muslims in carrying out some of their worship rituals; $;^{10}$ the direction to the Kaaba (Mecca) passes through the nearest route that every muslim must face in that direction during prayers; ${ }^{11}$ and the direction or the shortest distance along the large circle passing through the city of Mecca (Kaaba) to the location of the city where they live in. ${ }^{12}$ Thus, the qibla pressure point is regarding the direction (syathr), namely the direction of the Kaaba in Mecca in accordance with surah al-Baqarah (2): 144. From any point or place on the surface of the earth, the direction (syathr) of the Kaaba can be determined by calculation and measurement. The calculation of the direction (syathr) of the qibla is a calculation to find out which direction the Kaaba is in when seen from a place on the surface of the earth, so that all movements of people who are praying, whether standing, bowing, or prostration, always point to the direction (syathr) of the Kaaba.

The society's view of the direction, in general, is always identical to the north, east, south, and west, so that when they see the position of a place on the map to the east of Mecca, the qibla is to the west, likewise other directions. Even though, there are other directions that can be read through a compass, such as the northeast, southeast, southwest, and northwest. In astronomy or hisâb, the calculation of the qibla direction depends on the geographical location of the place where the qibla direction is being calculated, so that the qibla direction cannot be generalized by simply mentioning one of the eight cardinal directions (north, northeast, east, southeast, south, southwest, west, and northwest) because the reference is the final value of the calculation that refers to one direction only.

${ }^{7}$ Abû Bakar Aḥmad ibn al- $\underline{H}$ usain ibn 'Alî al-Baihaqî, al-Sunan al-Kubrâ, ed. 'Abd al-Qâdir 'Atâ, vol. II (Beirut: Dâr al-Kutub al-'Ilmîyah, 2003), p. 16.

${ }^{8}$ Ahmad Warson Munawwir, Kamus Al-Munawwir: Arab-Indonesia (Yogyakarta: Pustaka Progresif, 1984), p. 1169.

9 Departemen Pendidikan Nasional, Kamus Besar Bahasa Indonesia Pusat Bahasa (Jakarta: Gramedia Pustaka Utama, 2013), p. 695.

${ }^{10}$ Nasrun Haroen, Ensiklopedi Hukum Islam, eds. H. Abdul Aziz Dahlan, vol. III (Jakarta: Ichtiar Baru van Hoeve, 1996), p. 944.

${ }^{11}$ Slamet Hambali, Ilmu Falak I (Tentang Penentuan Awal Waktu Shalat dan Penentuan Arah Kiblat di Seluruh Dunia) (Semarang: Pascasarjana IAIN Walisongo, 2011), p. 84.

${ }^{12}$ Muhyiddin Khazin, Ilmu Falak dalam Teori dan Praktik (Yogyakarta: Buana Pustaka, 2005), p. 50. 


\section{Basic Law of Qibla in Salat}

The provision of facing qibla during prayer is explicitly explained in surah al-Baqarah (2): 144, 149, and 150 and the hadith narrated by Abû Hurairah in al-Sunan al-Kubrâ by alBaihaqî. ${ }^{13}$ Based on this verse and hadith, the scholars made individual interpretation and judgment (ijtihâd) as well as agreed that facing the qibla is a condition of the validity of prayer. The difference between them is related to the time when someone could not see the Kaaba directly. According to Abû Ishâq Ibrâhîm ibn 'Alî al-Syîrâzî, a scholar of the Syafi'i school, for example, a person who is in al-Masjid al- Harâm must face the form or physical of the Kaaba ('ain al-Ka'bah). However, if he is not in al-Masjid al-Harâm, his provisions are as follows: if he knows the direction of qibla, then he must face that direction; if there is a person who is trusted to inform the existence of the qibla direction, then he should receive that information and there is no need for ijtihâd; and when he sees a group of people praying facing one direction, then he must follow it because the person who sees the person praying is the same as the person who knows the direction of qibla through a trusted person. ${ }^{14}$

\section{Methods for Determining the Direction of the Qibla and Requirements for the Validity of} Prayers

Although not evenly distributed, the development of science and technology has contributed greatly to determining the direction of the qibla in Indonesia, because the development of science and technology must be directly proportional to the educational level of each astronomer. Some groups have used modern equipment, but other groups are still using systems that are considered outdated. This cannot be separated from various factors, such as the various knowledge levels of muslims, the introversion in accepting knowledge, ${ }^{15}$ and limited costs for obtaining the equipment.

In practice, the accuracy and precision of determining the qibla direction are not solely due to the use of modern equipment, because commonly used tools such as a compass, for example, can help to obtain an accurate qibla direction as long as the calculation and measurement of the qibla direction are correct according to the rules of astronomy. This has

\footnotetext{
${ }^{13}$ al-Baihaqî, al-Sunan al-Kubrâ, vol. II, p. 16.

${ }^{14}$ Abû Ishâa Ibrâhîm ibn 'Alî ibn Yûsuf al-Syîrâzî, al-Muhadzdzab fî Fiqh al-Imâm al-Syâfi'̂̀, vol. I (Beirut: Dâr al-Kutub al-'Ilmîyah, n.d.), p. 130.

${ }^{15}$ Ahmad Izzuddin, Ilmu Falak Praktis: Metode Hisab-Rukyat Praktis dan Solusi Permasalahannya (Semarang: Pustaka Rizqi Putra, 2012), p. 29.
} 
been proven by a study on the accuracy of the qibla direction of mosques in Garut Regency, West Java. In the study, the qibla direction of seven mosques from 26 mosques that used a compass accompanied by calculations was declared accurate. ${ }^{16}$

One should use formula rules that are commonly applied by astronomers in order to get the precise result of hisab (calculation) of the direction (syathr) of the qibla. For example, by using the formula "cotan $\mathrm{B}=(\sin \mathrm{a} x \operatorname{cotan} \mathrm{b}): \sin \mathrm{C}-\cos \mathrm{a} \mathrm{x} \operatorname{cotan} \mathrm{C}$ ". This formula can only be applied in Indonesia because the result will point the direction from the north point to the west point $(\mathrm{N}-\mathrm{W})$. Another formula is an application that can be used for areas on the earth's surface as a whole, the results of which directly point the direction based on azimuth: "C = $320^{\circ} 10$ '19.6" + longitude of place. ${ }^{17}$ This formula can only be applied in Indonesia because the result will point the direction from the north point to the west point $(\mathrm{N}-\mathrm{W})$. Another formula is an application that can be used for areas on the earth's surface as a whole, the results of which directly point the direction based on azimuth: $C=320^{\circ} 10$ '19.6” + longitude of place ${ }^{18}, \sin \mathrm{h}=\left(\left(\sin\right.\right.$ latitude place ${ }^{19} \mathrm{x}$ sin latitude of the Kaaba $)+(\cos$ latitude place $\mathrm{x} \cos$ latitude Kaaba $x \cos C))$, $\cos Q=((-\tan$ latitude place $x \tan h)+($ sin latitude Kaaba: $\cos$ latitude place: $\cos \mathrm{h})$ ). If the value of $\mathrm{C}$ is greater than 180 , then the azimuth ${ }^{20}$ qiblais $=$ the value of $\mathrm{Q}$. If the value of $\mathrm{C}$ is less than 180 , then the azimuth qibla is $=360-\mathrm{Q} \cdot{ }^{21}$

In addition to the above formula, some people also use sunlight at certain times. This application is used to determine the shadow formed by the sun and point to the qibla position. Because the shifting of the sun every day is not the same, the shadow depends on the location and position of the place based on the coordinates of the latitude, longitude, and the sun's

${ }^{16}$ Maesyaroh, "Akurasi Arah Kiblat Masjid dengan Metode Bayang-bayang Kiblat (Studi Kasus di Kabupaten Garut),” Isthinbát: Jurnal Hukum Islam, vol. 12, no. 1 (June, 2013): 103-110.

${ }^{17}$ In that formula, $a=90$ - latitude of place, $b=90$ - latitude of Kaaba, $C=$ distance between longitude of place and longitude of Kaaba. Azhari, Ilmu Falak, p. 65; and Khazin, Ilmu Falak, pp. 55-6.

${ }^{18}$ Place longitude is the distance measured along the equatorial arc from longitude through the city of Greenwich to longitude through the place/country. Susiknan Azhari, Ensiklopedi Hisab Rukyat (Yogyakarta: Pustaka Pelajar, 2012), p. 47.

19 The latitude of a place is the distance along the earth's meridian measured from the equator to the place in question. Azhari, Ilmu Falak, p. 134.

${ }^{20}$ Azimuth is the value of an angle for a place or celestial body calculated along the horizon from the north to east point clockwise until the point of intersection between a vertical circle passing through a place or celestial body and the horizon circle. Muhyiddin Khazin, Kamus Ilmu Falak (Yogyakarta: Buana Pustaka, 2005), p. 40 .

${ }^{21}$ Hosen, Zenit: Panduan Perhitungan Azimut Syathr Kiblat dan Awal Waktu Shalat (Pamekasan: Duta Media, 2016), p. 124. 
declination $^{22}$ on that date, so that the shadows of the sun in this formula application can be in the morning, noon, and evening. The formula is: $\tan K=(\operatorname{cotan} b x \sin a: \sin c-\cos a x \operatorname{cotan}$ c), $A z=90-K$, Tan $P=(\sin$ latitude place $x \tan A z), \operatorname{Sin} Q=(\tan$ sun's declination $x \sin P: \tan$ latitude of place $), B S K=((Q-P): 15)+M P-K W D{ }^{23}$

The media that can be used to determine or measure the direction of qibla include compass, rubu' mujayyab, angled triangle, arc, Global Positioning System (GPS) to determine the coordinate point, qibla locator, Mizwala Qibla Finder (MFQ), istiwa 'ain, theodolite, idzun dial, the shadow of the sun position, and the istiwâ' a'dzam events that occur on May 28 and July 16.

Islamic Sharia has determined that prayer is declared valid when the conditions and pillars are fulfilled. The conditions that must be fulfilled are: Islam, bâligh, entering prayer time, holy from small and large hadas, holy from najâsah, closed genitals, and facing the qibla. The Jurists (fuqahâ') agree in one understanding about the obligation to face the qibla in prayer, ${ }^{24}$ except for several conditions, namely: first, when the war rages and the society are under fright, under the state of force, and acutely ill. Second, when performing sunnah prayers on a vehicle. ${ }^{25}$ The legal basis used by jurists is surah al-Baqarah (2): 144. Therefore, a Muslim who wants to pray must know the direction of the qibla. If he does not know, either because there is no sign to follow or no information is obtained but enables to pick up on the signs, he is still obliged to try to find out the direction of the qibla. For example, he could use the common method by looking at the rays and the shadows of the sun, the moon, the position of the stars, and the direction of the wind. ${ }^{26}$

${ }^{22}$ The sun's declination is the distance of the sun along the declination circle calculated from the equator to the sun's position. Khazin, Kamus Ilmu Falak, p. 51.

${ }^{23}$ The variant of the formula can be explained: $a=90$ - latitude of place, $b=90$ - latitude of Kaaba, $c=$ longitude of place - longitude of Kaaba. The sun's declination is the distance between the sun's positions along the declination circle calculated from the celestial equator to the sun, either northward with a positive value or southward with a negative value. Meridian Pass (MP) is obtained from the 12 - equation of time (the time difference between the actual solar time and the mean solar time). Regional Time Correction (RTC) results from the longitude of the place - the longitude of the area/group divided by 15 .

${ }^{24}$ Wahbah al-Zuhailî, al-Fiqh al-Islâmî wa Adillatuh, vol. II (Damascus: Dâr al-Fikr, 1985), p. 597.

${ }^{25}$ Muhammad 'Alî al-Shâbûnî, Rawâ'i' al-Bayân Tafsîr Âyât al-Ahhkâm min al-Qur'ân, vol. I (Damascus: Maktabah al-Ghazâlî, 1980), p. 124; and Muhammad Nawawî al-Bantanî, Syarh Kâsyifah al-Sajâ 'alâ Safinah al-Najâ fî Ushûl al-Dîn wa al-Figh (Indonesia: Pustaka al-Iksan, n.d.), p. 49.

${ }^{26}$ al-Syîrâzî, al-Muhadzdzab, vol. I, p. 130. 


\section{The Understanding of the Society toward the Qibla Direction of the Mosque}

A mosque is a holy building for muslims, one of which functions as a place of worship, especially for prayers. As a place of prayer, mosques are built and shaped in such a way as to make users feel comfortable. One of the conditions is that the mosque must point to the qibla which is the facing target in the act of having prayer. The qibla that is used as a standard in Islam is the Kaaba in al-Masjid al- Harâm in Mecca. Based on the investigation to respondents, society in general needs knowledge and insight about the qibla and the aspects related to it. This is based on the fact that some people do not fully know the qibla which they make as a benchmark for facing when they pray.

Some people still think that the qibla is the west, as told by Slamet Riyadi, one of the congregations of Darul Mukhlisin Mosque, West Pademawu, Pamekasan. He did not know what to face and where to face, because he used to only follow the religious leaders and scholars facing the west when they prayed. ${ }^{27}$

The limited knowledge of the society about the direction of qibla is inseparable from two things, namely: first, the Islamic religious education taught to the previous society is influenced by the history of the entry of Islam into Indonesia brought by traders from India. The geographical location of India is to the east of Saudi Arabia. The custom of Indians when praying to faceto the west is brought to Indonesia. Though the geographical location of Indonesia is different from the geographical location of India. Second, the number of astrologers or astronomers who really understand the position of the direction of qibla is small, especially in Madura, although previous scholars have taught the procedure of finding the direction of qibla using a triangle.

In general, society will ask the opinion of local leaders or kiai when they are going to build a mosque or langgar. Even though the knowledge of astronomy possessed by this figure or kiai is inadequate, it is only based on information from other people that the qibla is somewhat oblique to the north from the west point. In addition, the actual position of the west point is not measured based on a compass, but is measured based on feelings and eyesight which are synchronized with the position of the road or ground at the mosque or langgar construction site. As a result, the direction of the mosqueor langgar's qibla is not in accordance with the direction of the qibla to the Kaaba. Even though they know how to measure the qibla direction

\footnotetext{
${ }^{27}$ Slamet Riyadi, congregation of Darul Mukhlisin Mosque Pademawu Barat, direct interview (June 24,
} 2019). 
with a compass, for example, they do not determine the angle value to be taken from west to north; only based on estimates that it is slightly inclined to the north so that the direction shown by the mosque building will not be precise towards the qibla direction in Mecca. Another factor that can affect the mismatch of the direction of the mosque's qibla even though it has previously been measured correctly is the inaccuracy of the construction of the mosque foundation on the line of prayer lines taken by the elbow.

Some people understand that prayer which is facing Allah The Almighty, by turning the face or body towards the qibla, does not have to be exactly precise towards the qibla but the most important thing is that the heart is solemn or devoted when praying. Such assumptions are not correct according to the sharia because they do not meet the requirements for the implementation of prayers, namely that the body is obliged to face the qibla. This is based on the word of Allah The Almighty in surah al-Baqarah (2): 144, 149, and 150 which clearly instructs to turn the face towards al-Masjid al- Harâm when praying in normal conditions.

The education forsociety about the qibla is needed. It can even be done as early as possible starting at the Elementary School level. Muslims should have an understanding of the qibla in all its aspects, although not all Muslims can measure the direction of the qibla. According to Muhammad Nawawî al-Jâwî (1813-1897 AD), there are four ways for a person to know the qibla and its direction, namely: first, he knows the shape of the qibla by seeing it, like someone who has visited al-Masjid al- Harâm in Mecca for hajj and umrah. Second, he gets information from people who are believed to know the qibla, such as information from people who have witnessed the shape of the qibla. Third, he performs ijtihâd in looking for the direction of the qibla, just like an astronomer who performs ijtihâd in looking for the direction of the qibla based on his knowledge. Fourth, he followed (taqlîd) the direction of the mujtahid (counting and measuring person of the direction of the qibla) who knew the shape, direction, and location of the qibla in accordance with the shape of the earth, which was then applied in a formula or other form and in accordance with the reality. Therefore, one is not justified to follow the ijtihâd of someone who does not know the exact shape and direction of the qibla which is only based on estimation. ${ }^{28}$

Scholars of the Syafi'i school explain the problem of qibla direction more clearly, namely: first, one knows well the direction towardqibla. If he can know for himself, then he must

${ }^{28}$ al-Bantanî, Syarh Kâsyifah al-Sajâ, p. 49. 
determine the direction of qibla according to his knowledge. Second, he asks people who understand and trusted in determining the direction of qibla by using equipment guided by the stars, the sun, and the moon. This is done when society do not know how to determine the direction of qibla. Third, he conducts ijtihâd by himself when no one is an expert in determining the direction of qibla, there is no means to know the direction of qibla, and there are no other instructions that are considered to lead to qibla, such as a mosque whose qibla direction is correct. Fourth, he follows the instructions that determine the direction of qibla, that is, when no one is an expert in determining the direction of qibla or no other guide that leads to qibla. ${ }^{29}$

The above statement shows that the determination of the direction of the qibla in the past, as happened in Pademawu District, Pamekasan has been done, namely by following the opinion of people who are considered to know the direction of the qibla even in a simple way. For example, he uses a compass, razor blade, or is guided by the westward inclining slightly to the north without knowing the exact direction of the qibla.

After the times have changed as it is today, the determination of the direction of the qibla should refer to the second level, namely asking people who understand and are trusted in determining the direction of the qibla. This is in line with the development of astronomy and the people who already know how to determine the direction of the qibla, both using right and precise technological equipment, using trigonometric formulas (spherical triangles) which are connected to celestial objects such as planets, satellites, and stars or a combination of the two. Therefore, technological developments should synergize with the increase of worship, particularly in determining the direction of the qibla which can be precisely determined towards the Kaaba in Mecca. Besides, by determining the accurate direction of the qibla, Allah The Almighty says. about the command to face the qibla and the sunnah of the Prophet who changed the direction of the qibla from al-Aqsha Mosque in Palestine to the Kaaba in Mecca and his teachings on how to practice qibla can be carried out properly and correctly.

\section{Society's Response to the Deviation of Mosque's Qibla}

Based on observations, of the nine mosques whose qibla direction deviated, both to the south and the north by more than five degrees, only two mosques had their prayer lines

29 'Abd al-Raḩmân al-Jazâ'rî, al-Fiqh 'alâ al-Madzâhib al-Arba'ah, vol. I (Beirut: Dâr Ihyâ' al-Turâts al-'Arabî, 1986), p. 198. 
changed to adjust the direction of the qibla based on the calculation results, namely Nurul Falah Mosque in Sopaah Village by lining the prayer lines by using the border of black ceramics and Al-Falah Mosque in Prekbun Village, Pademawu District by painting the ceramics on the mosque prayer lines with black color, but other mosques remain as before. This indicates that the society, especially the mosque board, does not pay enough attention to the requirements for carrying out prayers, especially the direction of the qibla. Surprisingly, when being confirmed regarding the validity or illegality of people performing salat without facing the qibla, $81.5 \%$ of respondents answered that their prayers were invalid. A phenomenon that is not parallel between mind and fact.

This is evident from the nine mosques that experienced quite high deviation from the qibla direction (five degrees either the north or the south), only two mosques permanently changed their prayer lines, while the rest still did not change their prayer lines. The following two pictures can illustrate this phenomenon.
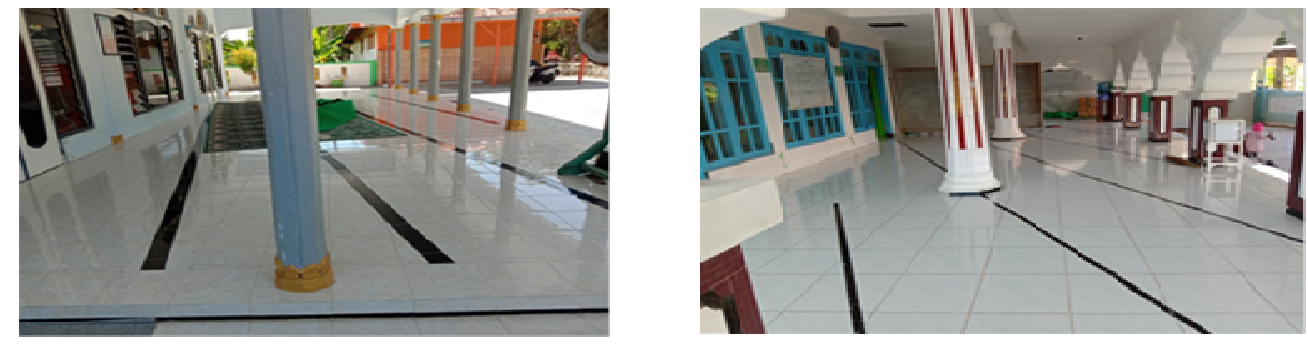

The change in prayer lines was carried out after several times measuring the qibla direction by different people at the initiative of the mosque board. These repeated measurements are used to compare the results and to convince the mosque administrators. Furthermore, the mosque board consults with mosque congregations to change prayer lines. Even though it took more than a year, finally the mosque board and the congregation agreed to change their prayer lines. This was taken to fulfill one of the requirements for the validity of the prayers and the benefit of the congregation who prayed in those two mosques.

Nurul Falah Mosque in Sopaah Village, as shown in the above picture, has a deviation of the qibla direction by $10^{\circ} 9^{\prime}$ to the north or less to the south. The origin of this deviation is unknown because the mosque board committee at the time of the initial research did not know it. This mosque was built on the foundation of the old mosque and without re- 
measurement. ${ }^{30}$ Meanwhile, the deviation of the qibla direction of Al-Falah Mosque in Prekbun Village is quite far, namely $24^{\circ} 9^{\prime}$ to the north or less to the south. According to one of its board officials, the initial measurement of the direction of the mosque's qibla was based on the instructions of a figure who was a role model at that time. This figure is considered to know the procedures for calculating and measuring the qibla direction. ${ }^{31}$ The researcher's investigation of the position and location of this mosque, which was confirmed by one of its board officials, showed that the direction of the qibla was guided by the location of the road beside it, which then took a slightly oblique direction to the north beside the location of the mosque building which was less symmetrical with the existing ground.

The effort of Nurul Falah Mosque board in Sopaah Village and Al-Falah Mosque board in Prekbun Village are examples of the implementation of moderation in fiqh in the direction of qibla. The process of raising awareness among board officials and congregation in these two mosques proves that moderation in fiqh requires bargaining value, which ultimately becomes a mutual agreement. At least, four moderation values can be learned from this case. First, honesty in responding and conveying the results of the calibration of the direction of the mosque's qibla following the science of hisâb. Second, openness in providing information related to the history of determining the qibla direction in the past and the latest qibla direction calibration results according to the data and calculation or the hisâb of the qibla direction. Third, the priority of love and brotherhood in responding to differences of opinion on the direction of the qibla. Fourth, be flexible in conveying the truth about deviations from the direction of the mosque's qibla. ${ }^{32}$

Nawawî al-Bantanî (1813-1897) explained the fourth prayer requirement, namely the intention of facing the correct qibla is to face the chest, both when standing and sitting (in prayer), to the physical qibla ('ain al-Ka'bah) not towards its direction (jihah) convincingly if the person praying is in an area near from the Kaaba and accompanied by an accurate prediction (dzann) for the person praying in a distant area. ${ }^{33}$ This opinion is based on the opinion of the scholars of the Syafi'i school when interpreting the verse "syathr al-masjid al-harâm", namely

\footnotetext{
${ }^{30}$ Ghafiruddin, Akurasi Arah Kiblat, p. 50.

${ }^{31}$ Ibid., p. 50.

${ }^{32}$ Abd. Karim Faiz, "Moderasi Fiqh Penentuan Arah Kiblat: Akurasi yang Fleksibel," JIL: Journal of Islamic Law, vol. 1, no. 1 (February, 2020): 96, https://doi.org/10.24260/jil.v1i1.23.

33 al-Bantanî, Syarh Kâsyifah al-Sajâ, p. 49. 
syathr is the front direction of the person praying and right on the azimuth line of the qibla, so that it faces to the physical qibla ('ain al-Ka'bah) is mandatory. ${ }^{34}$

Other mosques where the prayer lines have not been changed are Rahmatullah Mosque in Lemper Village where the qibla direction deviates from $11^{\circ} 51^{\prime}$ to the south or less to the north and Ash-Shinhaji Mosque in Sentol Village where the qibla is deviating $5^{\circ} 10^{\prime}$ to the north or less to the south. The prayer lines of the two mosques is made permanent with ceramics of different colors. Considering that the deviation is quite significant, the calibration of the two mosques' qibla direction should be done. The mosque board must communicate with congregations and society, especially local community leaders.

The responses from the result of interview with representatives of the mosque board, whose qibla directions encountered deviation, are different. This difference in response, both to the mosque board and the congregation, illustrates the various conditions of society's thought in responding to deviations in the direction of the qibla. Their responses can be grouped into serious, casual, and indifferent responses, which fully return to the education and knowledge of the mosque board and congregation about the obligation to face the qibla during prayer.

The technological touch is urgently conducted to detect the qibla direction via an Androidbased cellphone. This method is worth taking, because the average person, including the mosque board and the congregation, use it. The recommended Android-based qibla direction detection software is software whose validity has been tested because there is software that is not based on astronomical principles. Therefore, software testing needs to be done before being disseminated to the public, including its strengths and weaknesses. Software for simulating the determination of the qibla direction of mosques, langgar, hotels and housing can save time, effort, and thoughts as the current trend. People in general want convenience and instant way in all things, including the determination of qibla direction.

\section{The Implication of the Deviation of the Mosque's Qibla Direction on the Validity of Salat}

The law of studying the science of astronomy as a complement to the implementation of muslim worship, especially to determine the direction of the qibla in prayer, is fardh kifâyah (a joint obligation for mukallaf, which when one of them is carried out, the other person is free from this obligation). Embedding fardh kifâyah in studying the science of astronomy is

34 al-Shâbûnî, Rawâ'i' al-Bayân, vol. XI, p. 25. 
considered sufficient to answer the needs of muslims based on the area where they live. Communication between residents is needed to obtain information about people who can determine the direction of the qibla.

Determining the direction of the qibla is an obligatory act that must be carried out because facing the qibla correctly is a prerequisite for the validity of prayer. The error in determining the direction of the qibla made by previous figures that were considered to know how to determine the direction of the qibla was caused by four factors, namely: first, it was not measured according to the correct principles of astronomy. Second, it is measured, but the measurement is incorrect or just an estimation. Third, it is measured by referring to the existing road without having accuracy with a direction such as a compass. Fourth, it is measured using a compass carried by the pilgrims from Mecca, which is different from a compass in general.

Geographically, Indonesia is located in the southeast of Saudi Arabia. If drawn straight in general, the direction obtained is the direction between southeast and northwest. Because the coordinates of each place are used as a reference (the Kaaba with the local location), there must be a difference in lines between a location from another location according to the location or coordinate point. As a case in point, the coordinates of the Kaaba in this article are $21^{\circ} 25^{\prime}$ 14,7” North Latitude, 39 49” 40" East Longitude. Checking the direction of the mosque's qibla just needs to adjust to the coordinates of each. The composition of the formula used is: $\mathrm{C}=320^{\circ} 10^{\prime} 19,61^{\prime \prime}+$ place longitude $\operatorname{Sin} \mathrm{h}=((\sin$ mosque latitude $\mathrm{x} \sin$ Kaaba latitude $)+(\cos$ mosque latitude $\mathrm{x}$ cos Kaaba latitude $\mathrm{x} \cos C)$ )

$\operatorname{Cos} Q=((-\tan$ mosque latitude $x \tan h)+(\sin$ Kaaba latitude: $\cos$ mosque latitude: $\cos h))$.

If value C> 180, then azimuth syathr qibla = value $Q$. Different if value $C<180$, then azimuth syathr qibla $=360$ - value $Q$

For example, the compatibility of the qibla direction of Al-Falah Mosque in Prekbun Village with the coordinates of the mosque: ${ }^{35}$

$\begin{array}{ll}\text { Latitude } & : 07^{\circ} 12^{\prime} 05.03^{\prime \prime} \text { South Latitude }{ }^{36} \\ \text { Longitude } & : 113^{\circ} 29^{\prime} 39.00 ” \text { East Longitude } \\ \text { Latitude of Kaaba } & : 21^{\circ} 25^{\prime} 14,77^{\prime} \text { North Latitude }\end{array}$

\footnotetext{
35 The data collection of the mosque coordinates uses the Garmin Etrex 10 Global Positioning System (GPS), as well as the initial data collection by Ghafiruddin, Akurasi Arah, p. 69.

${ }^{36}$ In astronomy, negative values apply to South Latitude and West Longitude, and positive values for North Latitude and East Longitude as geographic differences.
} 
Longitude of Kaaba : $39^{\circ} 49^{\prime} 40^{\prime \prime}$ East Longitude

The data is then entered in the formula:

$\mathrm{C}=320^{\circ} 10^{\prime} 19,6^{\prime \prime}+113^{\circ} 29^{\prime} 39.00^{\prime \prime}$

$C=433^{\circ} 39^{\prime} 58.6^{\prime \prime}\left(433^{\circ} 39^{\prime} 58.6^{\prime \prime}-360\right.$ because more than $\left.360=73^{\circ} 39^{\prime} 58.6^{\prime \prime}\right)$

$\operatorname{Sin} \mathrm{h}=\left(\left(\sin -07^{\circ} 12^{\prime} 05.03^{\prime \prime} \mathrm{x} \sin 21^{\circ} 25^{\prime} 14,7^{\prime \prime}\right)+\left(\cos -07^{\circ} 12^{\prime} 05.03^{\prime \prime} \mathrm{x} \cos 21^{\circ} 25^{\prime} 14,7^{\prime \prime}\right.\right.$

$\left.\left.\mathrm{x} \cos 73^{\circ} 39^{\prime} 58.6^{\prime \prime}\right)\right)$

$\mathrm{h}=12^{\circ} 21^{\prime} 15.77^{\prime \prime}$

$\operatorname{Cos} Q=\left(\left(-\tan -07^{\circ} 12^{\prime} 05.03^{\prime \prime} \times \tan 12^{\circ} 21^{\prime} 15.77^{\prime \prime}\right)+\left(\sin 21^{\circ} 25^{\prime} 14,7^{\prime \prime}: \cos -07^{\circ} 12^{\prime}\right.\right.$

$\left.\left.05.03^{\prime \prime}: \cos 12^{\circ} 21^{\prime} 15.77^{\prime \prime}\right)\right)$

$Q=66^{\circ} 8^{\prime} 20,28^{\prime \prime}$

Because the value of $\mathrm{C}\left(73^{\circ} 39^{\prime} 58.6^{\prime \prime}\right)<180$, the azimuth syathr qibla of the mosque $=360$ $66^{\circ} 8^{\prime} 20.28^{\prime \prime}=293^{\circ} 51^{\prime} 39.7^{\prime \prime}$ NESW..$^{38}$ Meanwhile, the direction of the mosque building is: $318^{\circ} \mathrm{NESW},,^{39}$ so the difference is $318^{\circ}-293^{\circ} 51^{\prime} 39.7^{\prime \prime}=24^{\circ} 38^{\prime} 20.3^{\prime \prime}$ too north or less south. ${ }^{40}$ The position description is as follows:

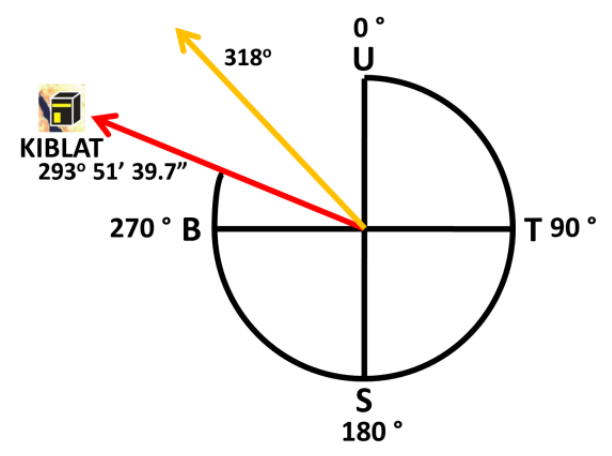

In the picture above, the red line is the qibla direction of Al-Falah Mosque in Prekbun Village, while the yellow line shows the deviation from the position of the Kaaba in Mecca to the north by $+/-24^{\circ} 38^{\prime} 20.3^{\prime \prime}$. If a straight line is drawn from the Kaaba to the north along the latitude, the yellow line will point to the Lipetsk area of a city in Russian territory. ${ }^{41}$ The distance from Al-Falah Mosque in Prekbun Village to the Kaaba in Mecca is approximately $8643.8222254 \mathrm{~km}$. If the deviation reaches 24 degrees to the north of the Kaaba, there will be attained a deviation in kilometers of $3594.3034 \mathrm{~km}$ from the Kaaba to the north.

\footnotetext{
${ }^{37}$ The latitude and longitude of the Kaaba use the data of Aḥmad Ghazâlî Muhamamad Fath Allâh, Anfa' al-Washîlah ilâ Ma'rifah al-Auqât al-Syar'îyah wa Simt al-Qiblah (Sampang: Ponpes al-Mubarak Lanbulan, n.d.), p. 29.

${ }^{38}$ Calculated based on the provisions of azimuth, namely from the north, east, south and west points.

${ }^{39}$ Ghafiruddin, Akurasi Arah, p. 49.

${ }^{40}$ Formula calculation using the Casio fx-350 MS calculator.

${ }^{41}$ Based on map searches using Google Earth Pro. 
The calculation of this distance and deviation is based on the following formula:

$\operatorname{Cos} \mathrm{M}=((\sin$ mosque latitude $\mathrm{x} \sin$ Kaabalatitude $)+(\cos$ mosque latitude $\mathrm{x} \cos$ Kaaba latitude $\mathrm{x} \cos$ (longitude of the mosque - longitude of the Kaaba))

Distance from the mosque to the Kaaba $=M: 360 \times 6,283185307 \times 6378,388^{42}$

Deviation $=$ distance: $\sin ((180-$ deviation value $): 2) \times$ sin deviation value

Then calculated using the Casio fx-5800P calculator yields the numbers below:

$\operatorname{Cos} \mathrm{M}=\left(\left(\sin -07^{\circ} 12^{\prime} 05.03^{\prime \prime} \mathrm{x} \sin 21^{\circ} 25^{\prime} 14.7^{\prime \prime}\right)+\left(\cos -07^{\circ} 12^{\prime} 05.03^{\prime \prime} \mathrm{x} \cos 21^{\circ} 25^{\prime} 14.7^{\prime \prime} \mathrm{x}\right.\right.$ $\left.\left.\cos \left(113^{\circ} 29^{\prime} 39.00^{\prime \prime}-39^{\circ} 49^{\prime} 40^{\prime \prime}\right)\right)\right)$

$\mathrm{M}=77^{\circ} 38^{\prime} 44,59^{\prime \prime}$

Distance from the mosque to the Kaaba $=77^{\circ} 38^{\prime} 44,59^{\prime \prime}: 360 \times 6.283185307 \times 6378.388$

The distance from the mosque to the Kaaba $=8643.822254 \mathrm{~km}$

Deviation $=8643.822254: \sin ((180-24): 2) \times \sin 24$

Deviation $=3594.3034 \mathrm{~km}$ from the position of the Kaaba to the north, because of the deviation of the mosque to the north position. Thus, the direction of Al-Falah Mosque qibla in Prekbun Village is very far from the Kaaba in Mecca.

To detect the presence of mosques with smaller qibla deviation, for example 5 degrees and 10 minutes of arc to the north such as Ash-Shinhaji Mosque in Sentol Village, the same method is used by changing the latitude and longitude of the mosque only. In calculation, it can be calculated as follows:

Mosque coordinate data:

Latitude $\quad$ : $07^{\circ} 08^{\prime} 06.83^{\prime \prime S o u t h ~ L a t i t u d e ~}$

Longitude $\quad: 113^{\circ} 30^{\prime} 38.85^{\prime \prime}$ East Longitude

Latitude of Kaaba : : $21^{\circ} 25^{\prime} 14.7^{\prime \prime}$ North Latitude

Longitude of Kaaba :3949’40” East Longitude

The data is then inserted in the formula:

$\mathrm{C}=320^{\circ} 10^{\prime} 19.6^{\prime \prime}+113^{\circ} 30^{\prime} 38.85^{\prime \prime}$

$C=433^{\circ} 40^{\prime} 58.45^{\prime \prime}\left(433^{\circ} 40^{\prime} 58.45^{\prime \prime}-360\right.$ because more than $\left.360=73^{\circ} 40^{\prime} 58.45^{\prime \prime}\right)$

$\operatorname{Sin} \mathrm{h}=\left(\left(\sin -07^{\circ} 08^{\prime} 06.83^{\prime \prime} \mathrm{x} \sin 21^{\circ} 25^{\prime} 14.7^{\prime \prime}\right)+\left(\cos -07^{\circ} 08^{\prime} 06.83^{\prime \prime} \mathrm{x} \cos 21^{\circ} 25^{\prime} 14.7^{\prime \prime} \mathrm{x}\right.\right.$ $\left.\left.\cos 73^{\circ} 40^{\prime} 58.45^{\prime \prime}\right)\right)$

${ }^{42}$ The value of $360=$ full circle, because the earth is assumed to be round. The value of 6.283185307 is the constant value of the formula, which until now researchers have not received information on its retrieval. The value of 6378,388 is the semidiamter value/radius between the northpole and the south pole. 
$\mathrm{h}=12^{\circ} 21^{\prime} 57.78^{\prime \prime}$

$\operatorname{Cos} Q=\left(\left(-\tan -07^{\circ} 08^{\prime} 06.83^{\prime \prime} \times \tan 12^{\circ} 21^{\prime} 15.77^{\prime \prime}\right)+\left(\sin 21^{\circ} 25^{\prime} 14.7^{\prime \prime}: \cos -07^{\circ} 08^{\prime}\right.\right.$ $\left.\left.06.83^{\prime \prime}: \cos 12^{\circ} 21^{\prime} 57.78^{\prime \prime}\right)\right)$

$\mathrm{Q}=66^{\circ} 9^{\prime} 26.78^{\prime \prime}$

Because the value of $\mathrm{C}\left(73^{\circ} 40^{\prime} 58.45^{\prime \prime}\right)<180$, the azimuth syathr qibla of the mosque $=360-$ $66^{\circ} 9^{\prime} 26.78^{\prime \prime}=293^{\circ} 50^{\prime} 33.22^{\prime \prime} \mathrm{NESW}$

Meanwhile, the direction of the mosque building is: $299^{\circ} \mathrm{NESW}$, so the difference is $299^{\circ}$ $293^{\circ} 50^{\prime} 33.78^{\prime \prime}=5^{\circ} 9^{\prime} 26.22^{\prime \prime}$ too north or less south. The position description is as follows:

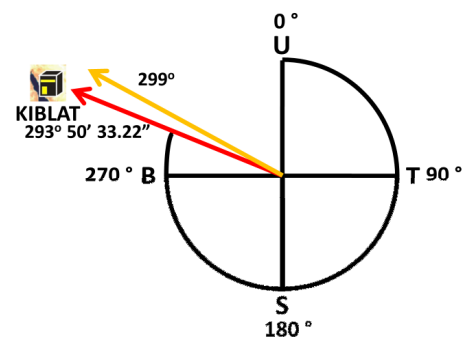

The results of calculating the distance and deviation are as follows:

$\operatorname{Cos} \mathrm{M}=\left(\left(\sin -07^{\circ} 08^{\prime} 06.83^{\prime \prime} \mathrm{x} \sin 21^{\circ} 25^{\prime} 14.7^{\prime \prime}\right)+\left(\cos -07^{\circ} 08^{\prime} 06.83^{\prime \prime} \mathrm{x} \cos 21^{\circ} 25^{\prime} 14.7^{\prime \prime} \mathrm{x}\right.\right.$ $\left.\left.\cos \left(113^{\circ} 30^{\prime} 38.85^{\prime \prime}-39^{\circ} 49^{\prime} 40^{\prime \prime}\right)\right)\right)$

$\mathrm{M}=77^{\circ} 37^{\prime} 53.51^{\prime \prime}$

Distance from the mosque to the Kaaba $=77^{\circ} 37^{\prime} 53.51^{\prime \prime}: 360 \times 6.283185307 \times 6378.388$

The distance from the mosque to the Kaaba $=8642.242537 \mathrm{~km}$

Deviation $=8642.242537: \sin ((180-5): 2) \times \sin 5$

Deviation $=753.9386 \mathrm{~km}$ from the position of the Kaaba to the north, because the deviation of the mosque is to the north position. Thus, the qibla direction of Ash-Shinhaji Mosque in Sentol Village deviates from the Kaaba in Mecca by $753.9386 \mathrm{~km}$ to the north. When drawn straight north from the position of the Kaaba, then $753 \mathrm{~km}$ indicates the suburb of Haif, an area which is still within Saudi Arabia but is far from Mecca. ${ }^{43}$

If the position of the two mosques is synchronized with the calculation of the science of astronomy and the hadith narrated by Abû Hurairah in al-Sunan al-Kubrâ by al-Baihaqî, ${ }^{44}$ then the tolerable deviation of the qibla direction minimally leads to the Mecca. With a deviation of 5 degrees to the north from Mecca, the direction to be aimed is far from the area of Mecca

\footnotetext{
${ }^{43}$ Search via Google Earth Pro.

${ }^{44}$ al-Baihaqî, al-Sunan al-Kubrâ, vol. II, p. 16. 
even to the border of Mecca to the north which is about 7-9 $\mathrm{km}$ from al-Masjid al- Harâm. Based on this fact, the deviation of the direction of the qibla of Ash-Shinhaji Mosque from the perspective of astronomy is not following the command to face the qibla in the Qur'an and hadith because the direction of the mosque building is still far from the direction of the location of Mecca as the minimal direction of the qibla that must be aimed by muslims at prayer.

According to al-Syâfi'î (767-820) and the majority of scholars of the Syafi'i school, a person who prays but is far from the Kaaba is still obliged to face straight to the Kaaba in a dzann (strong allegation) because when facing the qibla is obligatory then he must face straight to the qibla namely the Kaaba, and should not deviate because when deviating means he does not face the qibla. This is in accordance with God's command in surah al-Baqarah (2): $150 .{ }^{45}$ Meanwhile, according to Mâlik (711-795), the Kaaba is the qibla for the people in the Holy Mosque, the Holy Mosque is the qibla for the people of Mecca, and Mecca is the qibla for the people of the Holy Land, while the Holy Land is the qibla for muslims all over the world. ${ }^{46}$ This opinion is also based on the hadith narrated by Abû Hurairah in al-Sunan al-Kubrâ by alBaihaqî which has also been mentioned before. ${ }^{47}$

The scholars of the Hanafi and Hanbali school proposed a more convenient opinion. According to them, people who do not see the qibla directly are sufficient to point towards the qibla and do not need to ensure their position is straight to qibla or not. The important thing is that he already knows where the qibla direction is and he is facing it. According to them, as long as it is not said to turn away from the qibla as a whole, then it is still said to face the qibla. The meaning of "do not turn away as a whole" is if some of theface is still facing the qibla, either the front or the side. ${ }^{48}$ The opinion of the minority scholars of the Syafi'i school is also the same. One of them is al-Ghazâlî (1058-1111). Even so, they still need to have the intention to face the qibla, which is to the Kaaba. ${ }^{49}$ Scholars who only require to face the direction of

45 Wahbah al-Zuhailî, al-Fiqh al-Islâmî wa Adillatuh, vol. I (Damascus: Dâr al-Fikr, 1985), p. 758; and alShâbûnî, Rawâ'i' al-Bayân, vol. I, p. 125.

${ }^{46}$ Syihâb al-Dîn Mahmûd ibn 'Abd Allâh alal-Sab' al-Matsânî, vol. 1 (Beirut: Dâr al-Kutub al-'Ilmîyah, 1995), p. 408.

${ }^{47}$ al-Baihaqî, al-Sunan al-Kubrâ, vol. II, p. 16.

48 al-Alûsî, Rûh al-Ma'ânî, vol. I, p. 408; and Ach. Muhyiddin Khatib, Fikih Progresif Bunga Rampai Pemikiran Santri Ma'had Aly dalam Buletin Tanwirul Afkar (Situbonto: Ibrahimy Press, 2014), pp. 74-5.

49 al-Alûsî, Rûh al-Ma'ânî, vol. I, p. 408. 
qibla put forward some propositions to strengthen their opinion. One of them is the hadith narrated by Abû Hurairah as follows:

$$
\text { مَا بَيْنَ الْمَشْرِقِ وَالْهَغْرِبِ قِبْلَةُ }
$$

"The position between east and west is qibla" 50

In this hadith, the Prophet Muhammad PBUH did not specifically mention the Kaaba as the qibla, but only indicated the direction. Moreover, the straight position to the Kaaba is indeed very difficult to correct, whereas Islam does not require difficulties for the followers. Besides, the scholars have agreed that if there is a prayer congregation in which the shafis long, it is still considered to be facing the qibla, although there must be some congregations who do not face the Kaaba straight because the length of the Kaaba is only $12.7 \mathrm{~m}$. Thus, facing straight at the Kaaba is not a must. The obligation to face straight to the qibla is when they are in al-Masjid al-Harâm because doing so is easy. This is different from the position of muslims who are far from the Kaaba. However, in this modern era, there is already a way to determine the direction of the qibla that is sophisticated and accurate, namely by utilizing GPS technology that has been applied in the qibla locator and Google Earth.

Thus, correcting the direction of the qibla must be conducted, especially for mosques where the direction of the qibla has encountered deviationbecause the accuracy of the qibla direction is important so that it does not deviate far from the actual direction of the qibla. Because prayer is a religious obligation and commandment, facing the direction of the qibla and at the same time fixing the position of the place of prayer towards the qibla is a religious obligation and command. Accept it or not, qibla error is something that might happen. Especially if the determination is only based on the knowledge that the qibla is in the northwest. This study shows that there are still many mosques whose qibla direction is far from the direction of theqibla direction, namely the Kaaba.

The mistake when performing prayer without facing straight forward to qibla does not make the prayer fail since the mistake is only lying on having 'less to the right or to the left'. However, leading to the qibla in prayer and correcting the direction of the mosque that does not lead to the qibla remains important, so that the prayer becomes perfect. This is the opinion of some scholars of the Syafi'i school. Similarly, if we follow the opinion of the scholars of the

${ }^{50}$ Muhammad ibn 'Abd al-Hâdî al-Sanadî, Hâsyiyah al-Sanadî 'alâ Sunan Ibn Mâjah (Beirut: Dâr al-Jail, n.d.), p. 317. 
Hanafi or Hanbali School because according to them the position that is not leading in the direction of qibla is still considered facing the qibla. ${ }^{51}$ That is, although there is a deviation, even the body of the person who prays is not said to turn his back on the qibla is still considered facing the qibla. Especially during salat, the fact that the purpose is to face Allah Swt., Not to face the creatures as the Kaaba is made of stone and in the shape of a cube.

\section{Conclusion}

The majority of Society understands the direction of the qibla is the Kaaba at al-Masjid alHarâm in Mecca, so salat is declared valid if it faces the qibla. The minority of the society understands the direction of the qibla which is actually used as a benchmark for facing during salat is the direction of the wind, which is northwest. Even some of them do not understand the provisions of having to face the qibla when performing salat, because they only follow the habits that they imitate from their predecessors.

Some groups of society responded to qibla deviation seriously. This was marked by consolidation and deliberation between the mosque board with congregation and community leaders to find a solution so that they agreed to change the prayer lines at the mosque. The change of prayer lines is a marker for prayers that lead to the qibla. Meanwhile, some groups of society responded casually and even seemed indifferent. They assume that changing a mosque that has a deviation from the qibla direction costs a lot of money, creates conflicts between the congregation and the mosque board, reduces the aesthetic value of the mosque's interior, confuses the congregation, and erodes their belief. According to them, facing the qibla during prayer is a personal belief.

Socialization movements to the society regarding the direction of the qibla prayer, especially in mosques, are needed because some people are ignorant of deviations from the direction of the mosque. This socialization movement can be in the form of community service carried out by universities or institutions that are competent in the fields of hisâb and ru'yah.

\section{References}

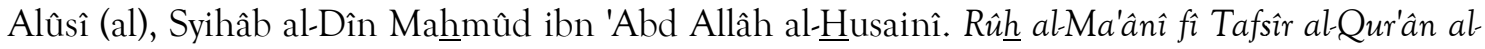
'Adzîm wa al-Sab' al-Matsânî, vol. I. Beirut: Dâr al-Kutub al-'Ilmîyah, 1995.

${ }^{51}$ Khatib, Fikih Progresif, p. 78; and al-Alûsî, Rûh al-Ma'ânî, vol. I, p. 408. 
Azhari, H. Susiknan. Ensiklopedi Hisab Rukyat. Yogyakarta: Pustaka Pelajar, 2012.

—_. Ilmu Falak: Teori dan Praktek. Yogyakarta: Lazuardi, 2001.

Baihaqî (al), Abû Bakar Aḥmad ibn al-Husain ibn 'Alî. al-Sunan al-Kubrâ, vol. II. Beirut: Dâr alKutub al-'Ilmîyah, 2003.

Bantanî (al), Muhammad Nawawî. Syarh Kâsyîfah al-Sajâ 'alâ Safinah al-Najâ fî Ushûl al-Dîn wa alFiqh. Indonesia: Pustaka al-Iksan, n.d.

Departemen Agama RI. Pedoman Penentuan Arah Kiblat. Jakarta: Dirjen Bimbaga, 1994.

Departemen Pendidikan Nasional. Kamus Besar Bahasa Indonesia Pusat Bahasa. IV. Jakarta: Gramedia Pustaka Utama, 2013.

Faiz, Abd. Karim. "Moderasi Fiqh Penentuan Arah Kiblat: Akurasi yang Fleksibel.” JIL: Journal of Islamic Law, 1 (1): 83-99, https://doi.org/10.24260/jil.v1i1.23.

Fath Allâh, Ahmad Ghazâlî Muhammad. Anfa' al-Washîlah ilâ Ma'rifah al-Auqât al-Syar'îyah wa Simt al-Qiblah. Sampang: Ponpes al-Mubarak Lanbulan, n.d.

Ghafiruddin. Akurasi Arah Kiblat Masjid di Wilayah Kecamatan Pademawu Kabupaten Pamekasan Menurut Metode Pengukuran Mizwala Qibla Finder (MQF). Thesis, STAIN Pamekasan, 2018.

Hambali, Slamet. Ilmu Falak I (Tentang Penentuan Awal Waktu Shalat dan Penentuan Arah Kiblat Di Seluruh Dunia). Semarang: Pascasarjana IAIN Walisongo, 2011.

Haroen, H. Nasrun. Ensiklopedi Hukum Islam, vol. III. Jakarta: Ichtiar Baru van Hoeve, 1996.

Hosen. Zenit: Panduan Perhitungan Azimut Syathr Kiblat dan Awal Waktu Shalat. Pamekasan: Duta Media, 2016.

Izzuddin, H. Ahmad. Ilmu Falak Praktis: Metode Hisab-Rukyat Praktis dan Solusi Permasalahannya. Semarang: Pustaka Rizqi Putra, 2012.

Jaza'irî (al), 'Abd al-Rahmân. Kitâb al-Fiqh 'alâ al-Madzâhib al-Arba'ah, vol. I. Beirut: Dâr Ihyâ' alTurâts al-'Arabî, 1986.

Khatib, Ach. Muhyiddin. Fikih Progresif Bunga Rampai Pemikiran Santri Ma'had Aly dalam Buletin Tanwirul Afkar. Situbonto: Ibrahimy Press, 2014.

Khazin, Muhyiddin. Ilmu Falak dalam Teori dan Praktik. Yogyakarta: Buana Pustaka, 2005. . Kamus Ilmu Falak. Yogyakarta: Buana Pustaka, 2005.

Maesyaroh. "Akurasi Arah Kiblat Masjid dengan Metode Bayang-bayang Kiblat (Studi Kasus di Kabupaten Garut).” Isthinbát: Jurnal Hukum Islam, 12 (1): 93-123.

Mulyadi, Achmad et. al. Penentuan Waktu Shalat $\mathcal{E}$ Kalibrasi Arah Kiblat: Menakar Problematika Akurasi Masjid-masjid di Pamekasan Melalui Pengabdian Kepada Masyarakat Berbasis Syariah/Hukum. Sumenep: Al-Fatah, 2016.

Munawwir, Ahmad Warson. Kamus Al-Munawwir: Arab-Indonesia. Yogyakarta: Pustaka Progresif, 1984.

Shâbûnî (al), Muhammad 'Alî. Rawâ'i' al-Bayân Tafsîr Âyât al-Ahkhâm min al-Qur'ân, vol. 1. Damascus: Maktabah al-Ghazâlî, 1980. 
Sanadî (al), Muhammad ibn 'Abd al-Hâdî. Hâasyîyah al-Sanadî 'alâ Sunan Ibn Mâjah. Beirut: Dâr al-Jail, n.d.

Syîrâzî (al), Abû Ishâq Ibrâhîm ibn 'Alî ibn Yûsuf. al-Muhadzdzaab fî Fiqh al-Imâm al-Syâfi'î, vol. I . Beirut: Dâr al-Kutub al-'Ilmîyah, n.d.

Zuhailî (al), Wahbah. al-Fiqh al-Islâmî wa Adillatuh, vol. II . Damascus: Dâr al-Fikr, 1985.

. Wahbah. al-Fiqh al-Islâmî wa Adillatuh, vol. I . Damascus: Dâr al-Fikr, 2004. 